\title{
Dragon's blood secretion and its ecological significance
}

\author{
Joanna Jura-Morawiec ${ }^{1} \cdot$ Mirela Tulik $^{2}$
}

Received: 5 February 2016/ Accepted: 1 March 2016 / Published online: 19 March 2016

(c) The Author(s) 2016. This article is published with open access at Springerlink.com

\begin{abstract}
Dragon's blood is the name given to a red exudate produced by some plant species belonging to the genera Daemonorops, Dracaena, Croton and Pterocarpus. These are endemic to various parts of the globe. It is classified as a resin or latex depending on its mode of secretion and its chemical composition, which is species specific. This red substance functions in defence and is produced (a) constitutively and stored in preformed anatomical structures, or (b) by induction in response to traumatic events, such as mechanical injury, pathogen attack or invasion by insects. Apart from its defensive role in plants, dragon's blood is also a valuable natural resource renowned since antiquity for its diverse medicinal properties and uses in art. Despite the great importance of dragon's blood, our knowledge of the biological basis for its secretion is still incomplete. This review summarizes recent advances in the study of the anatomical basis for its secretion, and discusses its classification and ecological function. Bringing some clarity to these issues may also help in the commercial sourcing of dragon's blood.
\end{abstract}

Handling Editor: Michael Heethoff.

Joanna Jura-Morawiec

j.jura@gazeta.pl

Mirela Tulik

mirela.tulik@wl.sggw.pl

1 Polish Academy of Sciences Botanical Garden - Centre for Biological Diversity Conservation in Powsin, Prawdziwka 2, 02-973 Warsaw, Poland

2 Department of Forest Botany, Warsaw University of Life Sciences-WULS, Nowoursynowska 159, 02-776 Warsaw, Poland
Keywords Resin · Latex · Laticifers . Constitutive defence $\cdot$ Induced defence

\section{Introduction}

During the course of plant evolution, adaptation to biotic and abiotic stresses is often accompanied by modification of the organism on a range of different levels of organization that may involve changes to its morphology, physiology and biochemistry. Secretion of resin or latex is only one of many defence mechanisms that protect the plant against insect invasions or pathogen attacks (Langenheim 2003). Amongst the angiosperms occurs a small group of plants called dragon's blood trees that have the ability to produce a red substance referred to as dragon's blood, which has ecological properties. This group includes both monocotyledonous and eudicotyledonous species belonging to the genera Daemonorops, Dracaena, Croton and Pterocarpus (Gupta et al. 2008). Dragon's blood trees are endemic to various parts of the globe. The monocots Daemonorops spp. and Dracaena spp. are native to Southeast Asia, and to Socotra, Canary Islands, Madeira and Morocco, China and some countries of Southeast Asia, respectively (Roskov et al. 2015; http://e-monocot.org/), while the eudicots Croton spp. and Pterocarpus sp. are native to the countries of Central and South America (Weaver 1997; Wiersema and Leon 2013; Roskov et al. 2015). A list of species of dragon trees has recently been included in a survey by Gupta et al. (2008). Dragon's blood is variously classified as resin or latex, and may be produced by cells of the stem, leaves or fruit (Table 1), taking the form of drops or chips (Balfour 1883).

Besides its great importance for the plants that produce it, dragon's blood is also a natural resource valuable for 
Table 1 Botanical sources of dragon's blood and its contribution to plant defence mechanism

\begin{tabular}{lllll}
\hline Family & Genus & Species & Origin & Plant defence \\
\hline Monocots & & & & Fruit \\
Arecaceae & Daemonorops spp. & 6 & Stem, leaf & Induced \\
Asparagaceae & Dracaena spp. & 3 & & Constitutive \\
Eudicots & & & Stem & Constitutive \\
Euphorbiaceae & Croton spp. & 8 & Stem & \\
Fabaceae & Pterocarpus sp. & 1 & & C \\
\hline
\end{tabular}

The number of species after Gupta et al. (2008)

humans. Its antiviral, antibacterial and antifungal properties have been known since antiquity (reviewed by Gupta et al. 2008). Currently, the antioxidant properties of its extract are used by the cosmetic industry in the production of antiageing skin creams. Studies are also being conducted to verify its anti-cancer properties (e.g. Rossi et al. 2003; Lopes et al. 2004; Gonzalez and Valerio 2006). The increasing demand of this natural resource has resulted in the overexploitation of dragon's blood-producing trees, and this is one of the factors that have adversely affected the size of their populations. Mainly, this affects Dracaena spp. By now, both Dracaena draco and D. cinnabari, the original sources of dragon's blood have been included in the IUCN (International Union for Conservation of Nature) Red List of Threatened Species [http://www.iucnredlist.org/], and D. cochinchinensis, which is a main source of red resin in China, has been recognized as an endangered species in that country (Anon 1987 after Wang et al. 2011). Although dragon's blood and its properties have been known since ancient times, our knowledge of the anatomical basis for its secretion by plants remains incomplete. One of the reasons for this may be the restricted distribution of dragon's blood trees. The aim of this article is to summarize the current state of knowledge regarding the anatomical and ecological aspects of dragon's blood secretion. Bringing some clarity to these issues may also help in the commercial sourcing of dragon's blood.

\section{The anatomical basis for the secretion of dragon's blood}

Secretion and storage of resin in conifers, as well as latex in eudicotyledonous plants, both herbaceous and tree species, are usually associated with the formation of specialized anatomical structures, such as resin ducts and laticifers, respectively. In the stem of monocot arborescent plants of the genus Dracaena, however, these special secretory structures are absent (Fan et al. 2008). Instead, dragon's blood is produced by cells of the parenchymatous ground tissue surrounding the primary and secondary vascular bundles, as well as by cortex cells located adjacent to the secondary protective tissue (Jura-Morawiec and Tulik 2015). These cells have no specific morphological/ anatomical traits and can currently be identified only on the basis of their red-coloured contents. The secretion of dragon's blood in stems of D. cochinchinensis has been observed only in individual plants no younger than 30-50 years (Wang et al. 2010a). In D. draco, the onset of secretion is not determined by age, and thus, dragon's blood is produced by young stems (Jura-Morawiec and Tulik 2015). Red exudate has also been detected in leaf cells of $D$. cochinchinensis, D. cambodiana (Wang et al. 2010b; Ou et al. 2013) and in D. draco (Fig. 1a); however, the structural basis for its secretion has not yet been described.

In the genus Croton, dragon's blood is secreted by nonarticulated laticifers and/or nonspecialized parenchyma cells (Rudall 1987; Farias et al. 2009). The former are more numerous in the phloem, whereas the latter are abundant in the cortex. Laticifer abundance varies in Croton spp. and is determined by (a) the age of the plant, (b) its position on the tree, and (c) the environment. In general, laticifers are less abundant in old than in young stems (Rudall 1994); the branches have greater laticifer densities than the stem, and trees of the tropical rain forest have more laticifers than those of semi-deciduous tropical forests (Farias et al. 2009).

Nowadays, most dragon's blood for commercial use is gathered from immature fruits of rattan palms of the genus Daemonorops (Pearson and Prendergast 2001; Baumer and Dietemann 2010). However, neither the anatomical basis for its secretion in this species, nor for the stem of Pterocarpus sp. has yet been described in the literature.

\section{Dragon's blood: resin, latex or sap?}

According to Langenheim (2003) resin "is a lipid-soluble mixture of volatile and non-volatile terpenoid and/or phenolic secondary compounds that are usually secreted in specialized structures located either internally or on the 

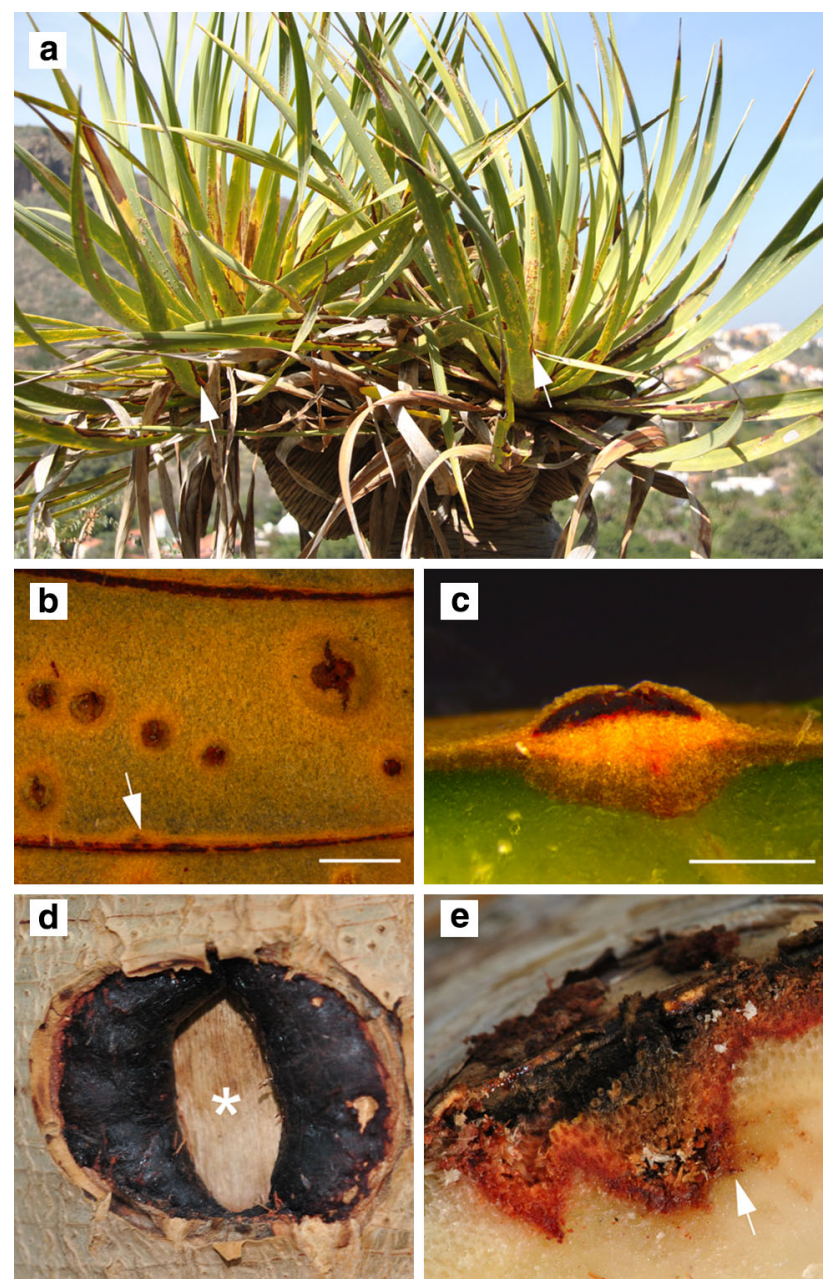

Fig. 1 Dragon's blood of Dracaena draco. a Dragon's blood tree growing at Jardín Botánico Canario "Viera y Clavijo" with leaves infected by Cochinilla algodonosa, note the reddish-brown spots on their surface (arrows). b Leaf scar (arrow) and lenticels filled with resin on stem surface. c Cross section of a lenticel. d Stem wound with margins covered with resin, the central, dead part is marked with an asterisk. e Cross-sectional view of a stem wound; the dragon's blood forms a barrier that isolates the infected tissue from healthy tissues. Scale bar $\mathbf{b}, \mathbf{c}=1 \mathrm{~mm}$

surface of the plant and are of potential significance in ecological interactions". By contrast, latex, is a mixture of terpenoids, phenolic compounds, acids, carbohydrates, etc. having a protective role (Lewisohn 1991) and produced in special cells called laticifers (Fahn 1979). Chemical characterization of dragon's blood is species specific and has been undertaken by many authors. For example, it is possible to distinguish between dragon's blood from some individual species used in works of art, since it has been sold as a colourant for many centuries (Baumer and Dietemann 2010). Dragon's blood of Croton spp. is usually referred to as latex due to the fact that it is secreted and stored by laticifers, and its major constituents are poly- meric anthocyanidins, which co-occur with many minor constituents, including diterpenes and simple phenols (Salatino et al. 2007). Dragon's blood secreted by stems of Pterocarpus officinalis is also called latex (Weaver 1997; Guerrero and Guzman 2004); however, information about the chemical composition of the exudate and its ecological function is poorly known. Dragon's blood derived from species of Dracaena and Daemonorops is a phenolic resin (Langenheim 2003), with well-recognized chemical content (e.g. Gonzalez et al. 2000; Shen et al. 2007; Sousa et al. 2008). Sometimes, dragon's blood is referred to as sap (e.g. Philipson 2001). However, this could prove to be a source of confusion, since plants produce other exudates referred to by that name, such as xylem sap and phloem sap, which are entirely different in terms of their location, chemical composition and function. Xylem sap is transported along xylem vessels and tracheids, is mainly composed of water, and contains several other components such as hormones and minerals, whereas phloem sap flows along sieve tubes (in angiosperms) and contains sugars, amino acids, hormones and minerals dissolved in water (Zimmermann and Brown 1971).

\section{Red latex/resin as a plant defence strategy}

Dragon's blood may act in constitutive or induced plant defence directed against pathogens, as well as against pests (Table 1). As mentioned above, the chemical composition of dragon's blood is species specific, and is thus likely to vary greatly with respect to the type of insects/pathogens that may attack a given species of dragon's blood tree. In Croton draco, dragon's blood is found in laticifers of the cortex and phloem, and represents a constitutive (preformed) defence. Since the bark of $C$. draco is very thin, it provides little mechanical resistance, and dragon's blood, together with oils and tannins probably act as effective deterrents against sucking insects and pathogens (Farias et al. 2009). In Pterocarpus sp., dragon's blood flows freely when the bark is cut (Allen 1964), and therefore, one might expect it to play a role in constitutive plant defence. Dragon's blood which coats the immature fruits of Daemonorops spp. also seems to be a part of a constitutive defence strategy. Lev-Yadun et al. (2009) pointed out that the red colour of unripe fruit can serve as a warning system, deterring herbivores from consuming chemically or physically defended fruit, and thus, their still immature seed. Therefore, it is likely that dragon's blood is aposematic (sensu Lev-Yadun and Gould 2009; Lev-Yadun 2014). Moreover, by being sticky, it may physically and passively entrap small organisms and, owing to its toxic 
nature, kill them (Konno 2011). Possibly, it can also protect against water loss and high temperatures (Langenheim 2003).

In Dracaena spp., dragon's blood secretion can be considered an induced natural defence mechanism, i.e. trauma is essential for triggering its formation. This can be due to mechanical injury, insect attack or pathogen infection (Fig. 1). Also localized tissue damage resulting from natural developmental processes, such as leaf drop or the formation of lenticels, may also induce dragon's blood secretion, as in D. draco (Fig. 1b, c). Moreover, it has been shown that infection with the pathogenic fungi Fusarium (Wang et al. 2010a, 2011; Jiang et al. 2003), Gibberella and Septoria (Cui et al. 2013) stimulates the production and accumulation of resin in Dracaena spp. Following a traumatic event, dragon's blood is synthesized and accumulates in the cells that border the wound or infected tissues. In this way, it helps prevent the spread of the pathogen and acts as a barrier between the wound/infected cells and healthy tissues (Fig. 1e) (sensu Shigo 1984). During the process of wound repair, dragon's blood coats the margins of the wound (Fig. 1d) providing additional protection, possibly against desiccation. The red colouration indicating the presence of resin appears about two weeks following the wounding of a $D$. draco stem (JuraMorawiec and Tulik 2015). This indicates that at first, the plant relies mainly on constitutive bark defences in the form of polyphenolic inclusions or calcium oxalate crystals (Nagy et al. 2000; Nakata 2012), both of which have been documented for Dracaena spp. (Prychid and Rudall 1999; Jura-Morawiec and Tulik 2015).

\section{Summary}

Dragon's blood secretion is a specialization occurring in a small group of plant taxa. Its composition and mode of secretion combine to produce effective defence mechanisms that have evolved along different pathways in species distributed across the globe. For some species, this feature has become a double-edged sword. On the one hand, it provides natural defence, but on the other, it makes the plant vulnerable to exploitation. Considering that some dragon's blood tree species are in decline, it becomes increasingly important that the secretion of dragon's blood is understood to help establish a sustainable harvest of red resin/latex for commercial use.

Acknowledgments J. J-M thanks colleagues from Jardín Botánico Canario "Viera y Clavijo" (Gran Canaria, Spain) for providing information on insects that affect the leaves of Dracaena draco. This study was funded by the Polish Academy of Sciences Botanical Garden-Centre for Biological Diversity Conservation in Powsin under the statutory fund.

\section{Compliance with ethical standards}

Conflict of interest The authors declare that there is no conflict of interest.

Open Access This article is distributed under the terms of the Creative Commons Attribution 4.0 International License (http:// creativecommons.org/licenses/by/4.0/), which permits unrestricted use, distribution, and reproduction in any medium, provided you give appropriate credit to the original author(s) and the source, provide a link to the Creative Commons license, and indicate if changes were made.

\section{References}

Allen PH (1964) The timber woods of Panama. Ceiba 10:17-61

Balfour IB (1883) The dragon blood tree of Socotra, vol 30. Translation Royal Society, Edinburgh, pp 619-623

Baumer U, Dietemann P (2010) Identification and differentiation of dragon's blood in works of art using gas chromography/mass spectrometry. Anal Bioanual Chem 397:1363-1376

Cui JL, Wang C, Guo SX, Xiao PG, Wang ML (2013) Stimulation of dragon's blood accumulation in Dracaena cambodiana via fungal inoculation. Fitoterapia 87:31-36

Fahn A (1979) Secretory tissues in plants. Academic Press, London

Fan LL, Tu PF, Xe JX, Chen HB, Cai SQ (2008) Microscopical study of original plant of Chinese drug "dragon's blood" Dracaena cochinchinensis and distribution and constituents detection of its resin. Zhongguo Zhong Yao Za Zhi 33:1112-1117

Farias FR, Williamson JS, Rodriguez SV, Angeles G, Portugal VO (2009) Bark anatomy in Croton draco var. draco (Euphorbiaceae). Am J Bot 96:2155-2167

Gonzalez GF, Valerio LG (2006) Medicinal plants from Peru: a review of plants as potential agents against cancer. Anti Cancer Agents Med Chem 6:429-444

Gonzalez AG, Len F, Sanchez-Pinto L, Padrn JI, Bermejo J (2000) Phenolic compounds of dragon's blood from Dracaena draco. J Nat Prod 63:1297-1299

Guerrero RO, Guzman AL (2004) Bioactivities of latexes from selected tropical plants. Rev Cubana Plant Med 9:1-6

Gupta D, Bleakley B, Gupta RK (2008) Dragon's blood: botany, chemistry and therapeutic uses. J Ethnopharmacol 115:361-380

Jiang DF, Ma P, Yang I, Wang XH, Xu K, Huang Y, Chen S (2003) Formation of blood resin in abiotic Dracaena cochinchinensis inoculated with Fusarium 9568D. Chin J Appl Ecol 14:477-478

Jura-Morawiec J, Tulik M (2015) Morpho-anatomical basis of dragon's blood secretion in Dracaena draco stem. Flora 213:1-5

Konno K (2011) Plant latex and other exudates as plant defense systems: roles of various defense chemicals and proteins contained therein. Phytochemistry 72:1510-1530

Langenheim JH (2003) Plant resins: chemistry, evolution, ecology and ethnobotany. Timber Press, Portland, Cambridge

Lev-Yadun S (2014) Why is latex usually white and only sometimes yellow, orange or red? Simultaneous visual and chemical plant defense. Chemoecology 24:215-218

Lev-Yadun S, Gould KS (2009) Role of anthocyanins in plant defence. In: Gould K, Davis K, Winefield Ch (eds) Anthocyanins: biosynthesis, functions, and applications. Springer Science and Business Media, New York, pp 22-28

Lev-Yadun S, Neeman G, Izhaki I (2009) Unripe red fruits may be aposematic. Plant Signal Behav 9:836-841

Lewisohn TM (1991) The geographical distribution of plant latex. Chemoecology 2:64-68 
Lopes MIL, Saffi J, Echeverrigaray S, Henriques JAP, Salvador M (2004) Mutagenic and antioxidant activities of Croton lechleri sap in biological systems. J Ethnopharmacol 95:437-445

Nagy E, Franceschi VR, Solheim H, Krekling T, Christiansen E (2000) Wound-induced traumatic resin duct development in stems of Norway spruce (Pinaceae): anatomy and cytochemical traits. Am J Bot 87:302-313

Nakata PA (2012) Plant calcium oxalate crystal formation, function, and its impact on human health. Front Biol 7:254-266

Ou L, Wang XH, Zhang Ch (2013) Production and characterization of dragon's blood from leaf blades of Dracaena cambodiana elicited by Fusarium proliferatum. Ind Crop Prod 45:230-235

Pearson J, Prendergast HDV (2001) Daemonorops, Dracaena and other dragon's blood. Econ Bot 55:474-477

Philipson DJ (2001) Phytochemistry and medicinal plants. Phytochemistry 56:237-243

Prychid ChJ, Rudall PJ (1999) Calcium oxalate crystals in monocotyledons: a review of their structure and systematics. Ann Bot 84:725-739

Rossi D, Bruni R, Bianchi N, Chiarabelli C, Gambari R, Medici A, Lista A, Paganetto G (2003) Evaluation of the mutagenic, antimutagenic and antiproliferative potential of Croton lechleri (Muell. Arg.) latex. Phytomedicine 10:139-144

Roskov Y et al (2015) Species 2000 \& ITIS Catalogue of Life, 23rd December 2015. Digital resource at http://www.catalogueoflife. org/col. Species 2000: Naturalis, Leiden, the Netherlands. ISSN 2405-8858

Rudall P (1987) Laticifers in Euphorbiaceae-a conspectus. Bot J Linn Soc 94:143-163

Rudall P (1994) Laticifers in Crotonoideae (Euphorbiaceae): homology and evolution. Ann Missouri Bot Gard 81:270-282

Salatino A, Faria Salatino ML, Negri G (2007) Traditional uses, chemistry and pharmacology of Croton species (Euphorbiaceae). J Braz Chem Soc 18:11-33
Shen C-C, Tsai S-Y, Wei S-L, Wang S-T, Shieh B-J, Chen C-C (2007) Characterization and determination of six flavonoids in the ethnomedicine "Dragon's Blood" by UPLC-PAD-MS. Nat Prod Res 21:377-380

Shigo AL (1984) Compartmentalization: a conceptual framework for understanding how trees grow and defend themselves. Ann Rev Phytopathol 22:189-214

Sousa MM, Melo MJ, Parola AJ, Seixas de Melo JS, Catarino F, Pina F, Cook FEM, Simmonds MSJ, Lopes JA (2008) Flavylium chromophores as species markers for dragon's blood resins from Dracaena and Daemonorops trees. J Chromatogr A 1209(1-2):153-161

Wang XH, Zhang Ch, Yang LL, Yang XH, Lou JD, Cao Q, GomesLarajno J (2010a) Enhanced dragon's blood production in Dracaena cochinchinensis by elicitation of Fusarium oxysporum strains. J Med Plant Res 4:2633-2640

Wang XH, Zhang CH, Wang Y, Gomes-Laranjo J (2010b) Screen of micro-organisms for inducing the production of dragon's blood by leaf of Dracaena cochinchinensis. Lett Appl Microbiol 51:504-510

Wang XH, Zhang Ch, Yang LL, Gomes-Laranjo J (2011) Production of dragon's blood in Dracaena cochinchinensis plants by inoculation of Fusarium proliferatum. Plant Sci 180:292-299

Weaver PL (1997) Pterocarpus officinalis Jacq. Bloodwood. Department of Agriculture, Forest Service, Southern Forest Experiment Station U.S. SO-ITF-SM-87, New Orleans

Wiersema J, Leon B (2013) World economic plants: a standard reference. CRC Press, Boca Raton, London, New York

Zimmermann MH, Brown CL (1971) Trees structure and function. Springer-Verlag, New York, Heidelberg, Berlin 